\title{
IS BUSYNESS A NEW TREND AMONG WHITE COLLARS?
}

\author{
Çiğdem KAYA ${ }^{1 *}$ \\ Begüm ÖTKEN ${ }^{2}$ \\ Senem GÖL BEŞER ${ }^{3}$
}

\author{
Received Date (Başvuru Tarihi):18/12/2018 \\ Accepted Date (Kabul Tarihi):01/03/2019 \\ Published Date (Yayın Tarihi): 25/03/2019
}

\begin{abstract}
When asked how their lives are, the most popular answer that people give is that they are busy all the time. Being busy indicates working long hours and lacking leisure time. While research on social status has primarily focused on money as an indicator of one's social status, it is important to know whether the factors (in our case, busyness) other than money have an effect on the perception of one's social status. The aim of this study is to investigate whether devoting more time to work is a demonstration of higher social status. With this aim, the relationship between busyness and social status is examined. Data for the study were collected from 225 whitecollar employees working in banking, textile, chemical, and construction sectors in Istanbul, Turkey. According to the findings, no significant relationship was found between busyness and social status. Based on additional general questions in the questionnaire, most of the respondents reported that they see themselves as busy persons and have a social status above average.
\end{abstract}

Keywords: Busyness; Social Status; Routine; Leisure time; Working Long Hours

JEL Code: M10, M19

\section{MEŞGUL OLMA BEYAZ YAKALILAR ARASINDA YENİ BİR TREND Mİ?}

\section{$\ddot{O} Z$}

Hayatlarının nasll olduğu sorulduğunda, insanların verdiği en popüler cevap, sürekli meşgul olmalarıdır. Meşgul olmak uzun saatler çalışmayı ve boş zamana sahip olmamayl ifade etmektedir. Sosyal statüye iliş̧kin araștırmalar öncelikle sosyal statünün bir göstergesi olarak paraya odaklanırken, para dışındaki faktörlerin (bu çalışmada meşgul olmanın) kişilerin sosyal statü alglları üzerinde bir etkisi olup olmadı̆̆ını bilmek önem arz etmektedir. Bu çallş̧manın amacl, işe daha fazla zaman ayırmanın daha yüksek bir sosyal statü göstergesi olup olmayacağını araşstırmaktır. Bu amaçla meşgul olma ile sosyal statü arasındaki ilişkiyi incelenmektedir. Araş̧tırma için veri, İstanbul, Türkiye'de bankacıllk, tekstil, kimya ve inşaat sektörlerinde çalışan 225 beyaz yakalı çalışandan toplanmıştır. Bulgulara göre, meşgul olma ve sosyal statü arasında anlaml bir ilişki bulunmamıştır. Ankette yer verilen ek sorulara dayanarak, yanıt verenlerin çoğu kendilerini yoğun kişiler olarak gördüklerini ve ortalamanın üzerinde bir sosyal statüye sahip olduklarını bildirmişlerdir.

Anahtar Kelimeler: Meşgul Olma; Sosyal Statü; Boş Zaman; Uzun Çalışma Saatleri

JEL Kodu: M10, M19

\footnotetext{
${ }^{1}$ Dr. Instructor, Istanbul Arel University, cigdemkaya2810@ gmail.com *Corresponding Author

${ }^{2}$ Assoc. Prof. Dr., University of North Carolina Wilmington, begumotken@ hotmail.com

${ }^{3}$ Assoc. Prof. Dr., Yeditepe University, senemgol@yeditepe.edu.tr
} 


\section{INTRODUCTION}

In a world of 'constantly occupied', whenever we are asked of our state of being", we find ourselves eager to respond as "very busy, indeed!" The answer comes almost automatically. Celebrities and many people complain that they have no life. "I am very busy" has a quite different meaning specifically among employees nowadays. Are we too busy to mind the busyness? Recently, it has been argued that individuals' representations of their states of busyness play an important role in establishing their positions in social stratification (Gershuny, 2005). It is possible to say that hard-working and busy way of life result in greater implications of social status.

Individuals assess the status of others according to many indicators such as ethnicity, education, income, language, and occupation (Fişek, Berger, and Norman, 2005). Some of these indicators are related to each other and income, occupation, and education are frequently used by social science researchers as main signs of the broad objective status dissimilarities in society. For differentiating people, these differences are used and called socioeconomic status (Rogers and Onge, 2007; cited in Alfonsi, Conway, and Pushkar, 2011). Individuals also use owning expensive products as a way to express status through the value of these products. Living at the "right" address, driving the "right" car, wearing the "right" clothes and hanging out with the "right" people have always been used as symbols of status. For example, money and time are valuable and scarce resources, and owning them might be a symbol of status and wealth, too.

Although earlier inquiries mainly focused on money as a status symbol, conspicuous expenditure of time has drawn the attention of scholars in recent years. The new cultural and social studies of work assert that being busy and lack of leisure time indicate status by means of a person's value. The reason behind this recent interest might be attributed to the fastchanging society and work life. Ambition, hard work, success, and busyness became admirable and valued qualities among working people in modern society and people started to make more and more public that they are very busy. Because leisure has been considered as a behavior engaged in by the very wealthy since they did not have to work, or by laggards who refused to work (Williams, 1986). This is a pride evoking situation and indicates a social status.

This article focuses its attention on how people position their work and themselves as individuals within the abstract nature of time, whilst suggesting a conceptual field for examining and reconciling the relationship between busyness and social status of individuals. 
Economically, individuals may devote more time to work in order to earn more money and maintain their standard of living. In addition, busyness may be analyzed from the perspectives of time management, work requirements or work overload. However, the concept of busyness entails more than just earning more money and more than the perspectives of time management, work requirements or work overload. It has now turned out to be a powerful symbol of the status by means of a mechanism that shows the person is highly demanded and rare one.

In this paper, it is investigated whether devoting more time to work is a demonstration of higher social status. To do this, the relationship between busyness (i.e. working long hours and lacking leisure time) and social status is examined. Because research on social status has largely centered upon money as an indicator of one's social status, it is crucial to understand whether the factors, in our case, busyness, other than money have an effect on the perception of one's social status.

\section{THEORETICAL FRAMEWORK}

The theory of time and organization are combined in numerous diverse ways (see, eg., Bluedorn and Derhart, 1988; Clark, 1990; Gherardi and Stradi, 1988; Hassard, 1999; cited in Forray and Woodilla, 2002). Here, in this article, we focus on the abstract concept of time like "a resource that can be negotiated or symbolized, and is treated as real, yet simultaneously known through our experience of it." (Fine, 1990, p. 96).

\subsection{Busyness}

Basically, there are three methods accessible to sociologists and those who want to observe how time is being used (Kleermeier, 1961); one of them is examining the structure of monetary expenses for goods and services, another one contains the grading of numerous actions by the occurrence with which they occur among groups of individuals and finally the third one examines the amount of time that is divided into numerous actions within a certain time period (Yanowitch, 1963).

Busyness is defined as "long hours of remunerated employment and lack of leisure time" (Bellezza, Paharia and Keinan, 2017, p. 119). Leisure, on the other hand, is depicted as the freedom to pursue personal interests in the hieroglyphic inscriptions in Egyptian temples and tomb walls of nearly 4000 years ago. The ancient Greeks pondered the values of pursuing leisure behaviors for their own ends, such as in contemplation or music. Christians of the middle ages saw a valued leisure in religious contemplation. However, the industrial revolution reduced Western concepts of leisure to the narrow definition of that which is not work (Williams, 1986). 
Busyness is also an internalized impression of pressure, which creates a state where there is little time to achieve worthwhile work and which usually leads to a low energy level (Thompson et al., 2008). It is affected by elements such as the amount of work, problem and difficult situations handling ability and the degree of complexity of the environment (O'BrienPallas et al., 1997).

Figure 1 presents the conceptual map of busyness where the noticeable sources of busyness are defined as the environment, interpersonal factors associated to social interactions, intrapersonal factors on the basis of individual characteristics and finally cultural factors such as shared organizational/practice beliefs.

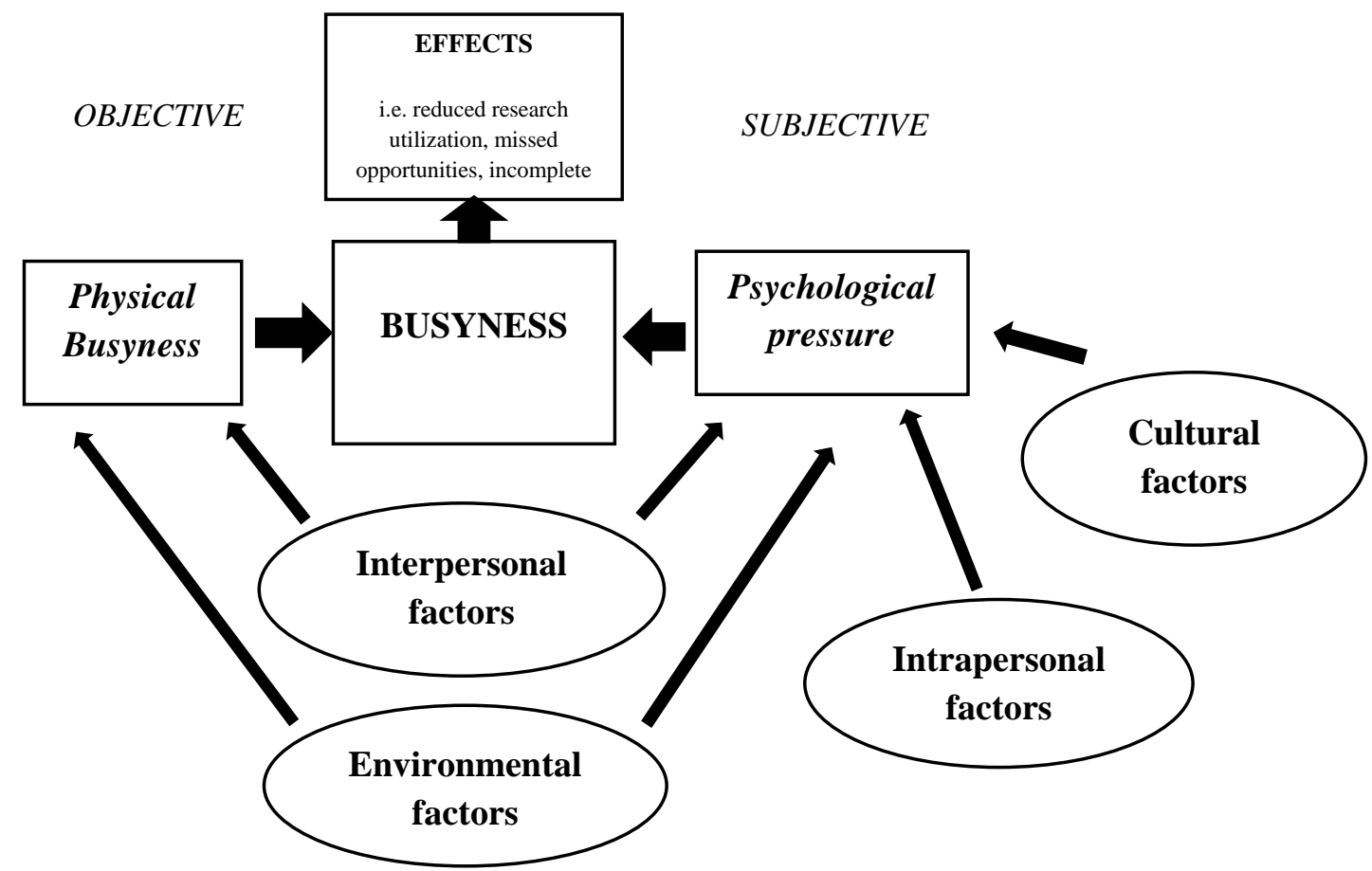

Figure 1. Conceptual Map of Busyness

Source: Thompson, D. S., O'leary, K., Jensen, E., Scott-Findlay, S., O'Brien-Pallas, L., \& Estabrooks, C. A. (2008). The relationship between busyness and research utilization: it is about time. Journal of Clinical Nursing, 17(4), 539-548.

Thompson et al. (2008) have categorized the noticeable sources of environmental factors influencing busyness as unit activities, workload, labor shortage, physical space or layout, paperwork, noise, interruptions, busywork, restricted resources, as well as the management (administration)'s control over autonomy in the workplace or practice.

Interpersonal factors contribute to the physical facets of busyness, as well as to the ascended psychological pressure since they are drawn from the relationships such as support staff, difficult family/patient, leadership responsibilities and interruptions (Thompson et al., 
2008). Intrapersonal factors are comprised of workers' personal attributes, demands of their personal lives, as well as their coping abilities. In general, intrapersonal factors are seen to mediate the individual perception of busyness (Thompson et al., 2008).

Culture is defined by Drennan (1992) as "the way things are done around here", and refers to the specific norms that reflect the attitudes, beliefs, rituals, activities that are gained through socialization and learning. Likewise, organizations are cultures that incorporate such things as rules, myths, stories, and special language (Bate, 1994; cited in Wilson et al., 2004) and defined as ways organizational members commonly think, behave and believe (Thomas et al., 1990; cited in Wilson et al., 2004). Professionals and organizations may create a culture in which busyness is appreciated and recompensed by forming group professional identity that suggests people being busy, providing no retreat/protected time, as well as dissuading idle time (Thompson et al., 2008). People fear idleness and want to be busy in pursuit of motivation and meaning in their existence (Ariely et al., 2008; Hsee et al., 2010; Keinan and Kivetz, 2011; Wilcox et al., 2016; cited in Bellezza et. al., 2017). As Williams (1986) puts it "even in these last decades of the $20^{\text {th }}$ century, there are many of us in so-called advanced societies who feel a little guilty if we are away from work too long, and even worse, a little uneasy if our work seems to have a touch of leisure in it".

National cultures view and evaluate busyness differently as well. In terms of the differences among national cultures and various beliefs on social mobility, Europeans see their leisure time as important as their working time, and even more important than that, whereas Americans regard work as primacy and overemphasize busyness (Richards, 1998, 1999; cited in Bellezza et al., 2017). In modern-day American culture, grouching about being busy, having crazy schedules, and working all the time has turned out to be a progressively pervasive phenomenon (Alford, 2012; Schulte, 2014).

French sociologist Dumazedier (1967) embraced leisure as an activity which is outside the obligations of the job, the family and the society, which the individual does freely in order to participate in the social life, explain her creative capacity and develop her knowledge, relax and satisfy the need for change. Thus, the concept has more than that of "nonwork" but rather the statement of a whole collection of human being's desires on a search for new bliss and humanistic mutation.

Human beings attitude towards leisure is developing whilst presenting some challenges for its interpretation. In a research carried out on workplace culture in a special care nursery, 
the findings recommended that nurses preserved an "image of busyness" that functioned as a bumper between themselves and their patients and families' demands (Wilson et al., 2005).

Hsee et al. (2009) proposed that people want busyness, but they are reluctant to look for busyness voluntarily without some justification. Their research also speculated the simultaneous wants for busyness and for justification of busyness as a part of evolution since human ancestors had to protect their energy to compete on rare resources and consume their energies in such a way that they would not risk their survival.

Thus, understanding the workplace busyness culture, as well as its relationship with the social status, is important to undertake effective developments in the practice of a given organization. If there are attempts to change an organizational culture that is multifaceted, the clarification of the values (i.e. social status) held among the workers would be the initial step.

\subsection{Social Status}

Status can be described as the relative ranking of an individual in a given group. According to Sorokin (1927), status can be discussed in many ways, including political, informational, economic, and social. Among the others, this study focuses on the social status and social status is defined as a position of increased interpersonal impact and social standing (Bourdieu, 1984).

Dubois and Ordabayeva (2015, p. 336) argue that social status exhibits one's ranking in a hierarchy and characteristically reveal the extent to which one is esteemed or appreciated by others. The idea that people can climb the social ladder, i.e. status can be achieved, leads to the possibility of people entering remarkable consumption and thus pointing out their social progress relative to others. In contrast, the status that is ascribed (i.e., predetermined, e.g., acquired by birth) can promote status signals that aim to strengthen a person's status. Based on the arguments of Dubois and Ordabayeva (2015), it can be said that an individual gets her status features in two forms: features that she is born with, for instance, wealth and family name, and features that an individual can achieve by herself such as education, occupation and job title.

Deephouse (1995) also argues that social status has two facets: descriptive and evaluative. The descriptive facet is related to the position of an individual in a social system on the basis of a number of relevant dimensions commonly related to roles. The evaluative facet refers to the ranking of an individual in terms of the values of a social system such as being important in society (Rostamy et al., 2008). Based on Deephouse's (1995) two facets of social status, it is thought that evaluative facet of social status may include individuals' busyness 
attribute. Ambition, hard work, and busyness are respected traits and are generally associated with success, importance, and wealth in Western culture. Evidence shows that being busy can evoke pride and is often made public to others through complaining or bragging (Kreider, 2012). Moreoever, Belezza et al. (2017) found that displaying one's busyness and lack of leisure signals status through the value of the person. Based on this evidence, it is thought that busyness may lead to greater inferences of social status and the following hypothesis is formulated:

$\boldsymbol{H}_{1}$ : The higher the level of busyness, the higher the perceptions of the social status of an individual will be.

In addition to the indicators of one's social status in the eye of others such as publicly consuming luxury goods, displaying busyness and lack of leisure time is another way to communicate status. While research on busyness and social status has been analyzed separately, there is a recent interest among their associations. Research shows that positive status implications originated from long hours of work and lack of leisure time are mediated by the perception that busy individuals have desirable human capital characteristics such as ambition and competence and that this leads them to be seen as rare and preferred individuals in the job market (Bellezza et al., 2017). Bellezza et al. (2017) have investigated how demonstrating busyness in the workplace affects status perceptions in other people's eyes. In one of the experiments, participators read a short characterization of a man who is 35 years old and works long hours and his agenda is constantly occupied. Conversely, participators in the other experiment read that this man does not show any effort for work and has a leisurely way of life. Subsequent to reading these scenarios, participants were asked to rate the perceived social status of the person depicted. As a result, researchers determined that the person who is very busy is seen as having a high status, and that remarkably status ascriptions are profoundly affected by our own opinions concerning social mobility. The more people believe that people have a success chance by working hard, the more people have a tendency to consider that people who do not use leisure time and work all the time have higher status.

\section{METHODOLOGY}

The aim of this study is to investigate whether devoting more time to work is a demonstration of higher social status. With this aim, the relationship between busyness (i.e. working long hours and lacking leisure time) and social status is examined. Because research on social status has primarily focused on money as an indicator of one's social status, it is 
important to know whether the factors (in our case, busyness) other than money have an effect on the perception of one's social status.

The data for the present study were drawn from white-collar employees working in banking, textile, chemical, and construction sectors in Istanbul, Turkey. Data were collected from 225 employees. Convenience sampling was used. Convenience sampling is "a type of nonprobability or nonrandom sampling where members of the target population that meet certain practical criteria, such as easy accessibility, geographical proximity, availability at a given time, or the willingness to participate are included for the purpose of the study." (Etikan, Musa, and Alkassim, 2016, p. 2). Some of the questionnaires used in the research were distributed by the researchers themselves and collected after they were completed by the participants. Another part of the questionnaires was distributed to the participants by easy-toreach people, back at the end of the response and sent to the researchers in closed envelopes. Data were collected within five months.

Busyness was measured by the Martin and Park Environmental Demands Scale developed by Martin and Park (2003). The scale consists of 11 questions. 7 questions measure Busyness and 4 items measure Routine. Participants were asked to read the questions and place an "X" for each question as it applied to them on a 6-point scale ranging from "always" to "never". Items are presented in the factor analysis in Table 1.

Need for social status was measured with a questionnaire developed by Flynn, Reagans, Amanatullah, and Ames (2006). The scale includes 8 items measuring social status. Respondents were asked to rate the extent to which they agreed with each item by placing an $\mathrm{X}$ on a 6-point scale ranging from "totally agree" to "totally disagree". Sample items include "Being a highly valued member of my social group is important to me" and "I enjoy having influence over other people's decision making”. Items 2 and 7 were reverse scored.

Subjective social status was measured with an instrument developed by Adler, Epel, Castellazo, and Ickovics (2000). A drawing of a ladder with 10 rungs was answered by respondents, and the ladder was designated as follows: "Think of this ladder as representing where people stand in our society. At the top of the ladder are the people who are the best off, those who have the most money, most education, and best jobs. At the bottom are the people who are the worst off, those who have the least money, least education, and worst jobs or no job." Then, the respondents were requested to put an $\mathrm{X}$ on the rung that characterizes their stand on the ladder in the best way. 
Two additional questions were added to the questionnaire in a separate section by the authors. One of the questions is "Do you see yourself as a busy person?" and the other question is "Do you think busyness is a status symbol?" These questions were quite general and used to measure the respondents' self-opinion about busyness and busyness-social status relationship.

The data is analyzed by using SPSS 22. Reliability analysis, factor analysis, and correlation analysis were run to get the results.

\section{FINDINGS}

The were started with the demographic characteristics. Based on the demographic characteristics, $68 \%$ of the sample are male and $61 \%$ are single. Concerning the education level, $70 \%$ of the sample has a bachelor's degree. Ages of the respondents range between 22 and 54 and $61 \%$ are between the ages of 22 and $30.76 \%$ of the sample have work experience from 1 to 10 years and $5 \%$ have been in working life for more than 19 years. $71 \%$ of the sample have a tenure between $1-5$ years, $25 \%$ between $6-12$ years and $4 \%$ between $13-22$ years.

Reliability analyses of the need for social status and busyness scales were run. The initial reliability analysis of the need for social status scale showed that the second item was lowering the reliability of the scale. Thus, the second item was eliminated from the analysis and Cronbach's Alpha was found as .705 for the need for social status scale. The eleventh item in the busyness scale was also eliminated from the analysis due to the low value and the reliability analysis was rerun. As a result, Cronbach's Alpha was found as .700 for the busyness scale.

In order to find the factor structure of need for social status, factor analysis was used by utilizing the principal components solution with a varimax rotation. Any item with a factor loading more than one factor or loading less than .50 was removed from the analysis. Factors with Eigenvalues 1.00 or more were taken into account in total variance explained.

10 items of busyness scale were entered into the factor analysis. Kaiser-Meyer-Olkin (KMO) value was found as .795 which was above the accepted value. This result marked the homogeneous structure of the variables and the result of the Bartlett Test (.000, Chi-Square: 972.027, df: .45) indicated that the variables were appropriate for the factor analysis. Items were loaded on two factors explaining $60.125 \%$ of the total variance. Considering the original factors (busyness and routine) that Martin and Park (2003) found as a result of their study, items in the analysis loaded on the same factors, too. Therefore, the resultant factors were named as busyness and routine. The results of the factor analysis are presented in Table 1. 
Table 1. Results of the Factor Analysis of the Busyness Scale

\begin{tabular}{lc}
\hline Factor 1: Busyness & Factor Loadings \\
\hline $\begin{array}{l}\text { How often are you so busy that you miss scheduled breaks or rest periods? } \\
\text { How busy are you during an average day? }\end{array}$ & .881 \\
How often do you have too many things to do each day to actually get & .826 \\
them all done? & .791 \\
How often do you find yourself rushing from place to place trying to get & .788 \\
to appointments or to get things done? & .705 \\
How often are you so busy that you miss your regular meal times? & .588 \\
How often do you have so many things to do that you go to bed later than & .576 \\
your regular bedtime? & \\
How often do you rush out of the house in the mornings to get to where & \\
you need to be? & \\
& \\
Factor 2: Routine & .860 \\
How often do you get out of bed in the morning and go to bed at night at & .828 \\
about the same time? & .587 \\
How often do you eat all of your meals at the same time each day and night? & \\
How often do your days follow a basic routine?
\end{tabular}

Social status was used as a composite score in the analyses.

In order to investigate the association between social status and busyness, correlation analysis was used. As a result of the correlation analysis, no significant relationship was found between social status and busyness factors, that is our hypothesis was not supported. Results are presented in Table 2.

Table 2. Correlations between Social Status and Busyness Factors

\begin{tabular}{lccc}
\hline & $\mathbf{1}$ & $\mathbf{2}$ & $\mathbf{3}$ \\
\hline Social Status & 1 & .003 & .041 \\
Busyness & 1 & $-.180^{* *}$ \\
Routine & & \multicolumn{3}{c}{1} \\
\hline \multicolumn{2}{c}{ ** Correlation is significant at the 0.01 level (2-tailed). }
\end{tabular}

\subsection{Results of the Dichotomous and Subjective Social Status Questions}

Two general questions were asked about busyness and the relationship between busyness and social status. One of the questions was "Do you see yourself as a busy person?". $78 \%$ of the respondents answered this question as "Yes". The second question was "Do you think busyness is a status symbol?" $76.5 \%$ of the respondents answered this question as "No".

Subjective social status was also measured by providing a drawing of a ladder with 10 rungs and asked respondents to put an X on the rung that characterizes their stand on the ladder 
in the best way. $29 \%$ of the respondents think that they stand on the $7^{\text {th }}$ rung, $24 \%$ on the $6^{\text {th }}$, $3.6 \%$ on the $10^{\text {th }}$ and $1.3 \%$ on the first rung of the ladder in terms of social status.

\section{DISCUSSION AND CONCLUSION}

Today in the fast-changing global environment, there is a dilemma of being "well-off and time scarce". Many people hear "I am very busy" as an answer to most of the "How are you?" questions and it has become a trendy answer for the last couple of years. It is not possible to find a person who is not busy nowadays since the "driven perceptions that a busy person possesses desired human capital characteristics and is scarce and in demand on the job market" (Bellezza et al., 2017). It was wondered whether this "I am very busy" answer has anything more than it means. The objective of this study was to make an attempt to understand the relationship between the busyness concept and social status.

Although social status and busyness concepts are demonstrated as interrelated in the literature (e.g. Gershuny, 2005; Bellezza et al., 2017), No significant relationship was found between these two concepts. We also found that although most of the respondents see themselves as a busy person, they do not think that busyness is a status symbol according to the analysis of the two general questions about busyness and the relationship between busyness and social status. These may be because of the evaluation and perception differences on busyness among national cultures (Richards 1998, 1999; cited in Bellezza et al., 2017).

According to Veblen (1899), in his theory of leisure class, there is a division of labor coinciding with the distinction maintained between working and the leisure class that is found in its best development at the higher stages of Barbarian cultures (e.g., feudal Europe and feudal Japan). The upper classes are by custom exempt or excluded from industrial occupations since they are reserved for certain employments to which a degree of honor attached. Status derives from the judgments that other members of the society make of an individual's position in the society and for this position to be established one must display wealth. Veblen (1899) identifies two ways an individual can display wealth and status: through extreme leisure activities and through lavish expenditure on consumption and services. This reveals that busyness is not important for the superior class since they are not required to work but rather engage in wasteful activities.

Indeed, Levine (2005, p. 355) underlines that how people conceive, measure and use time are the temporal norms of the culture, and these norms provide a highly informative framework for the value of people of this culture. Values related to busyness are the most 
prominent values which distinguish between cultures in terms of temporal values. Reeves $(2015$, p. 636) states that income might be an important indicator of social privilege and prestige based on the priorities of national cultures. Bellezza et al. (2017, p. 134) underlined that research has primarily indicated money as an important mean to signal status. However, in their research, they have explored how people spend their time can lead to the same end. The findings of the current study are different from this argument. In Turkey, busyness may not be the only signal for leading to a higher perception of social status contrary to the findings of Bellezza et al. (2017, p. 134). The sample of this study drawn from a Turkish population did not relate to busyness and social status. This shows that there are some other factors that need to be considered, such as income level, while investigating the link between busyness and social status concepts.

Even though no significant relationship was found between busyness and social status, it was found that busyness is a trend among white-collars, because $78 \%$ of our respondents answered that they see themselves as busy persons based on our general questions about busyness. Subjective social status was measured with a 10 rungs ladder. According to the findings, even though respondents do not associate busyness and social status, most of the respondents see themselves as having a social status above average.

Differentiation in income, education, profession, industry, and place of living variables identified differences in the patterns of consumption and lifestyle in Turkey (Aydin 2006, p. 463). Money, for example, is not considered to be an economic and rational thing in Turkish society but rather regarded as a means of particular rivalry and magnificence, social reputation and dignity (Ülgener 2006, p. 123). The occupation is the main indicator that reflects the position of the individual in the public space. The sense of the social status of society is considerably shaped by occupation. Nowadays, considering that the gained status for social prestige has become valuable, it can be said with ease that the occupation is among the primary conditions for the acquisition of status. Occupation is a fundamental determinant of the formation of the prestige level of this status as well as of the individual's social status. The level of prestige of social status that an occupation provides for its members is proportional to the level of social prestige of that occupation. Accordingly, the higher the prestige of occupation in the society, the higher the level of prestige of the social status it provides to its members. Therefore, the ability of an individual to gain a high prestigious social status depends primarily on their acquiring a highly prestigious occupation that will provide them with this status. This leads the occupations with a high social reputation to be the focus of continuous interest (illhan, 
2004). People with higher social positions perceiving their social status as essential to their identity and thinking consumption as a core motivation of life buy products and services to distinguish themselves from those lower social positions. According to Yeniaras's research from Turkey in 2016, the high status of the individuals affects their consumption behavior, and persons who consume to raise their social status do so inadvertently. For example, cell phones are perceived as a status symbol by Turkish consumers instead of solely perceiving them as a mobile communication tool (Dörtyol, Coşkun, and Kitapçı, 2018). As seen in the above examples, indicators of the social status of Turkish people vary from occupation to income and to consumption patterns, and this might be the reason why they see themselves as having a social status above average on the 10 rungs ladder and do not associate busyness and social status.

When interpreting the results of the present study, one of the limitations of this research was the small sample size. Larger samples enable the generalizations of the findings and provide more fruitful results. Another limitation was that a specific sector was not selected for the study. In order to obtain more generalizable conclusions on the relationship of busyness and social status, future studies might study these concepts in particular sectors such as information technology, banking or finance where individuals work more than the working hours determined by the law. Future studies may also focus on academicians who have the flexibility to plan and schedule their own work.

Income and national culture might be important variables for future studies to consider while studying these concepts. How individuals perceive and interpret busyness and social status concepts might be different depending on the income level and the cultural values they were raised with.

As for the final words, taking the predictions of Strumilin (1957 cited in Yanowitch 1963), it is advocated that "as the duration of working time declines with the growth of material abundance, and the nature of work becomes less burdensome and more creative, working time - like free time - becomes primarily an activity in which the full development of human capacities as an end in itself becomes capable of realization" that is; all busy time becomes leisure time. And perhaps the question will not be how many minutes less we work (and busy now) than we did a century ago, or tomorrow; however, the question will be what the constraints or possibilities of a given time unit such as the use of each hour are (Kaplan, 1968). 


\section{REFERENCES}

Adler, N.E., Epel, E.S., Castellazo, G. \& Ickovics, J.R. (2000). "Relationship of subjective and objective social status with psychology and physiological functioning: Preliminary data in healthy white women". Healthy Psychology, 19(6), 586-592.

Alfonsi, G., Conway, M. \& Pushkar, D. (2011). "The lower subjective status of neurotic individuals: Multiple pathways through occupational prestige, income and illness". Journal of Personality, 79 (3), 619-642.

Alford, H. (2012). "If I do humblebrag so myself, New York Times, December 2, ST2. Retrieved from https://www.nytimes.com/2012/12/02/fashion/bah-humblebrag-the-unfortunate-riseof-false-humility.html

Aydın, K. (2006). "Social Stratification and Consumption Patterns in Turkey", Social Indicators Research, 75(3):463-501.

Bellezza, S., Paharia, N. \& Keinan, A. (2017). "Conspicuous consumption of time: When busyness and lack of leisure time become a status symbol”. Journal of Consumer Research, 44, 118-138.

Bourdieu, P. (1984). Distinction: A social critique of the judgment of taste. Cambridge, MA: Harvard University Press.

Deephouse, D.L. (1995). Status. in N Nicholson, Dictionary of Organisational Behaviour. London: Blackwell Publisher.

Dörtyol, İ. T., Coşkun, A., \& Kitapçı, O. (2018). A Review of Factors Affecting Turkish Consumer Behavior. In S. Ozturkcan \& E. Yolbulan Okan (Eds), Marketing Management in Turkey, (pp.105-140). Emerald Publishing.

Dubois, D. \& Ordabayeva, N. (2015). Social Hierarchy, Social Status and Status Consumption, In M. I., Norton, D. D. Rucker, C. Lamberton (Eds.), The Cambridge Handbook of Consumer Psychology, (pp: 332-367). Cambridge University Press.

Dumazedier, J. (1967). Toward a society of leisure. Free Press.

Etikan, İ., Musa, S. A., \& Alkassim, R. S. (2016). "Comparison of Convenience Sampling and Purposive Sampling”. American Journal of Theoretical and Applied Statistics, 5(1): 1-4.

Falato, A., Kadyrzhanova, D., \& Lel, U. (2014). "Distracted directors: Does board busyness hurt shareholder value?". Journal of Financial Economics, 113(3), 404-426.

Fine, G. A. (1990). "Organizational time: Temporal demands and the experience of work in restaurant kitchens". Social Forces, 69(1), 95-114.

Fişek, M. H., Berger, J. \& Norman, R. Z. (2005). “Status Cues and the Formation of Expectations”, Social Science Research, 34(1), 80-102.

Flynn, F. J., Reagans, R. E, Amanatullah, E. T., \& Ames, D. R. (2006). "Helping One's Way to the Top: SelfMonitors Achieve Status by Helping Others and Knowing Who Helps Whom", Journal of Personality and Social Psychology, 91 (6), 1123-1137.

Forray, J. M., \& Woodilla, J. (2002). “Temporal spans in talk: doing consistency to construct fair organization”. Organization Studies, 23(6), 899-916.

Gershuny, J. (2005). "Busyness as the badge of honor for the new superordinate working class". Social Research 72(2): 287-314.

Hsee, C. K., Yang, A. X., \& Wang, L. (2010). "Idleness aversion and the need for justifiable busyness". Psychological Science, 21(7), 926-930.

İlhan, S. (2004). "Bazı Temel İşlevleri ve Artan Önemi Açısından Meslek” [Occupation in Terms of its Some Main Functions and Increasing Importance], Doğu Anadolu Bölgesi Araştırmaları; 132-137.

Kaplan, M. (1968). "Leisure as an issue for the future". Futures, 1(2), 91-99.

Kleemeier, R. W. (Ed.). (1961). Aging and leisure: a research perspective into the meaningful use of time. Oxford University Press.

Kreider, T. (2012). The Busy Trap, New York Times, June, 30, 2012. https://opinionator.blogs.nytimes.com/2012/06/30/the-busy-trap/ 
Levine, R. (2005). “A Geography of Busyness”, Social Research: An International Quarterly, 72(2), 355-370.

Martin, M. \& Park, D.C. (2003). "The Martin and Park environmental demands (MPED) questionnaire: Psychometric properties of a brief instrument to measure self-reported environmental demands". Aging Clinical and Experimental Research, 15, 77-82.

O'Brien-Pallas, L., Irvine, D., Peereboom, E., \& Murray, M. (1997). “Measuring nursing workload: understanding the variability". Nursing Economics, 15(4), 171-183.

Reeves, A. (2015). "Neither Class nor Status: Arts Participation and the Social Strata”, Sociology, 49 (4), 624-642.

Rogers, R.G. \& Onge, J.M.S. (2007). “Socioeconomic status, health, and mortality”. Blackwell encyclopedia of sociology. Retrieved May 21, 2009, from http://www.sociologyencyclopedia.com

Rostamy,A.A.A., Hosseini, H.K., Azar, A., Khaef-Elahi, A.A. and Hassanzadeh, A. (2008). 'Employees' social status in Iranian public and government organizations: Effect of individual, organizational and social factors". Singapore Management Review, 30(1), 77-98.

Schulte, B. (2014). Overwhelmed: work, love, and play when no one has the time, New York: Sarah Crichton Books.

Thompson, D. S., O'leary, K., Jensen, E., Scott-Findlay, S., O'Brien-Pallas, L., \& Estabrooks, C. A. (2008). "The relationship between busyness and research utilization: it is about time". Journal of Clinical Nursing, 17(4), 539-548.

Ülgener, S. F. (2006). "İktisadi Çözülmenin Ahlak ve Zihniyet Dünyası: Fikir ve Sanat Tarihi Boyu Akisleri ile bir Portre Denemesi", [The Economic Disintegration of the Moral and Mental Sphere], İstanbul: Derin yayınlar1.

Williams, F. (1986). The Communications Revolution, CA: Sage Publications.

Veblen, T. (1899). The Theory of the Leisure Class. In the Collected Works of Thorstein Veblen. Vol. 1. Reprint, London: Routledge, 1994, 1-404.

Wilson, V. J., McCormack, B. G., \& Ives, G. (2005). "Understanding the workplace culture of a special care nursery". Journal of Advanced Nursing, 50(1), 27-38.

Yanowitch, M. (1963). “Soviet patterns of time use and concepts of leisure”. Europe-Asia Studies, 15(1), 17-37.

Yeniaras, V. (2016). "Uncovering the relationship between materialism, status consumption and impulsive buying: newfound status of Islamists in Turkey". Journal for the Study of Religions and Ideologies, 15(44): 153177. 